\title{
Study of Leucorrhea Cases by Gram Stain and Aerobic Bacterial Culture
}

\author{
B. Sumangala, Akshatha B. Sangannavar, N.S. Sahana Shetty ${ }^{*}$ and \\ Kavya Shree M. Arun
}

Department of Microbiology, Mandya Institute of Medical Sciences, Mandya, India

*Corresponding author

\begin{tabular}{|l|}
\hline Ke y w o r d s \\
Bacterial vaginosis, \\
Gram staining, \\
Nugent's score, \\
Vaginitis
\end{tabular}

\section{A B S T R A C T}

Vaginitis is inflammation of cervical mucosa. Women who present with vaginal symptoms often complain of an abnormal discharge and possibly other symptoms such as an offensive odour or itching. The most common cause for vaginitis are Trichomoniasis, Candida Vaginitis (Moniliasis) and Bacterial Vaginosis. Vaginal discharge may be bloodstained or otherwise. Pathologically significant vaginal discharge can be white, cream, yellow or greenish discharge. Women coming to the outpatient department of Obstetrics and Gynaecology Department with complaints of white discharge per vagina were approached, explained about the purpose of the study and informed consent was taken. A non-lubricated Sim's speculum was inserted into the vagina after keeping the patient in dorsal position. An anterior vaginal wall retractor was used to retract the anterior vaginal wall. A high vaginal swab was taken using a sterile swab supplied by the Department of Microbiology. A smear was prepared for Gram's staining and culture plates, both blood agar and MacConkey's agar were inoculated and incubated. Out of the total 70 samples collected $25(36 \%)$ were positive for bacterial vaginosis and $45(64 \%)$ were negative. Cases of co-infection of bacterial vaginosis and Staphylococcus aureus (A gram positive cocci) and also Gram Negative bacilli (Escherichia coli, Klebsiella pneumonia, Gram negative non-fermenters were isolated. Direct microscopic examination of clinical material is often used in the diagnosis of bacterial vaginosis. In this study, we have evaluated the Gram's stain, standard clinical and microbiological (culture) criteria. In the present study the incidence of BV was $36 \%$. This correlates with other Indian studies performed by (Bhalla et al., 2007) which gave a result of $32.8 \%$ incidence of bacterial vaginosis

\section{Introduction}

Vaginitis is inflammation of cervical mucosa. Women who present with vaginal symptoms often complain of an abnormal discharge and possibly other symptoms such as an offensive odour or itching. The most common cause for vaginitis are Trichomoniasis, Candida Vaginitis (Moniliasis) and Bacterial
Vaginosis. Vaginal discharge may be bloodstained or otherwise. Pathologically significant vaginal discharge can be white, cream, yellow or greenish discharge.

Discharge caused by infection is mucopurulent or frankly purulent; its colour therefore varies from cream to yellow or green. It is often offensive, especially when 
coliform bacilli are present as primary or secondary invaders. Its chief microscopic characteristic is the presence of pus cells. The commonest lesions causing a discharge of this kind are as follows:

Vulvovaginitis: This may be due to infection with the gonococcus, Trichomonas vaginalis, Candida albicans or bacterial vaginosis in the adult, and with non-specific organisms in childhood and old age. Cervicitis gonococcal, chlamydial, anaerobic or puerperal or senile. Endometritis, puerperal or senile. Secondary infection of wounds, abrasions (including those caused by foreign bodies), burns, chemical injuries and neoplasms, sited in any part of the genital tract (Robert et al., 1991; Martinez-Martinez et al., 2014).

Herman Gardner and Dukes in the year 1955 described foul smelling discharge in women as non-specific vaginitis, which is now termed as Bacterial vaginosis. It was named so because bacteria are the etiologic agents and an associated inflammatory response is lacking. It is an alteration of normal vaginal bacterial flora that results in the loss of hydrogen peroxide-producing lactobacilli and an overgrowth of predominantly anaerobic bacteria. Lactobacilli are usually absent. It is not known what triggers the disturbance of normal vaginal flora. It has been postulated that repeated alkalinisation of the vagina, which occurs with frequent sexual intercourse or use of douches, plays a role. Most of the patients are asymptomatic. Perivaginal irritation, dysuria, dyspareunia are rare. Abdominal discomfort is complained by few patients. Women with BV are at increased risk for pelvic inflammatory disease (PID), postabortal PID, postoperative cuff infections after hysterectomy and abnormal cervical cytology. BV in pregnancy is known to be associated with adverse outcome like premature rupture of the membranes, preterm labour and delivery, chorioamnionitis, and postcaesare anendometritis. Women with BV are at increased risk of developing infection with N. Gonorrhoeae, Chlamydia trachomatis and Herpes Simplex virus-2, HIV. In the presence of co-infection the purulent discharge obscures BV (Ison and Hay. 2002).

Bacterial vaginosis is polymicrobial in etiology, usually Gardnerella vaginalis associated with other bacteria such as Lactobacillus, Prevotella, and anaerobes, including Mobiluncus, Bacteroides, Peptostreptococcus, Fusobacterium, Veillonella and Eubacterium. Mycoplasma hominis, Ureaplasma urealyticum, Streptococcus viridans and Atopobiumvaginae have also been associated with BV. Hence culture of Gardnerella vaginalis alone and non-culture tests cannot be considered as definitive diagnosis of BV. Molecular methods are also not useful since it is polymicrobial. Recurrence and treatment failure is fairly common unless it is diagnosed and treated with an oral agent and local application for prolonged period. Screening and treatment of BV is necessary before gynaecologic surgery and induction of abortion, to prevent pelvic inflammatory disease (PID). In recurrent BV both sexual partners need to be screened and treated (Carol et al., 1983).

Bacterial vaginosis is diagnosed popularly by Amsel's clinical criteria and in the laboratory by Nugent's criteria based on Gram's stain.

Bacterial vaginosis is diagnosed on the basis of the following findings:

A fishy vaginal odour, which is particularly noticeable following coitus, and vaginal discharge are present. b. Vaginal secretions are gray and thinly coat the vaginal walls. c. The $\mathrm{pH}$ of these secretions is higher than 4.5 (usually 4.7 to 5.7) d. Microscopy of the vaginal secretions reveals an increased number of clue cells, and leucocytes are conspicuously absent. e. The addition of $\mathrm{KOH}$ to the vaginal secretions (the "whiff" test) 
releases a fishy, amine-like odour. BV is the most common cause of vaginal symptoms among women of reproductive age. The percentage of women affected at any given time varies between $5 \%$ and $70 \%$.

Of the diagnostic methods currently available, assessment of clinical signs is subtle and detection of the signs is very dependent on the acuity of the clinician performing the test. In all cases of vaginitis it is difficult to clinically rule out all the causes. Definitive diagnosis is not possible based on signs and symptoms.

Empirical therapy based on clinical findings leads to-

1. Drug resistance 2.Inappropriate therapy 3 . Financial burden to the patient

Gram stained vaginal smears are the least expensive, require the least time to perform and are more widely available than other laboratory methods which can be preserved for later reference. However, this is the most interpretive of the laboratory methods. One study has shown that the Gram stain interpretation for diagnosis of bacterial vaginosis has high intracenter reliability.

Grading of the Gram stained smears of vaginal fluid reflects both the change in vaginal ecology and the strong microbial associations.

For performing Gram's stain, vaginal swabs have been collected from all patients attending the obstetrics and gynaecology outpatient department with complaints of excessive white discharge per vagina and analysed over the prescribed period of 2 months. Significant and relevant history has also been collected to correlate the clinical signs and symptoms and the laboratory analysis results. Culture of the procured samples has also been performed for further evaluation in case of any doubt regarding the causative organism. A holistic study has been performed and the report has been prepared after a detailed analysis of the results of the experiment.

We hereby propose to use the above mentioned technique as it is rapid, economical, accurate, reliable.

Microbiologically, bacterial vaginosis is characterized by a shift in the vaginal flora from the dominant flora of Lactobacillus spp. to a mixed vaginal flora that includes $G$. vaginalis, Bacteroides spp., Mobiluncus spp. and Mycoplasma hominis. As bacterial vaginosis is a clinical syndrome which has been associated with a group of genital microorganisms rather than a single etiologic agent, it has been defined primarily by certain clinical signs. Laboratory methods for diagnosis of bacterial vaginosis have included culture of Gardnerella vaginalis, direct Gram stain of vaginal secretions, biochemical tests for metabolic by-products of vaginal bacteria (gas chromatography) and more recently, the prolineaminopeptidase test (Robert et al., 1991).

Robert. P. Nugent and co-workers proposed a new scoring system that uses the most reliable morphotypes from the vaginal smear. The scoring system (0 to 10) was described as a weighted combination of the following morphotypes - lactobacilli, Gardnerella vaginalis or Bacteroides (small Gram variable rods or Gram negative rods) and curved Gram-variable rods as tabulated in Materials and methods of this article. The new scoring system is most successful in tackling intercenter variability (Robert et al., 1991).

A comparative study of various existing diagnostic methods for bacterial vaginosis were evaluated by W. Martinez et al., The three most commonly used methods for diagnosis of bacterial vaginosis are - Amsel's, Nugent's and Claeys' methods. The diagnosis of bacterial vaginosis by the three methods showed moderate concordance. Amsel's 
criteria - Based on clinical evidence and characteristics of vaginal discharge. Nugent's Score - The standard method and is used in epidemiological and research studies, based on the amount of different bacterial morphotypes present in vaginal ecosystem. Claeys' criteria - Based on the rate of Lactobacilli and bacterial vaginosis- associated bacterial morphotypes. Claeys' criteria is most effective, Nugent's method helps to make a subdiagnosis of the disease and Amsel's method contains criteria with poor sensitivity and specificity (Martinez-Martinez et al., 2014).

Ison and Hay in the year 2002, used Amsel's composite criteria to grade Gram-stained smears, which is still regarded as 'Gold standard'. This study states that, of the different scoring methods, the Amsel's criteria can be used as an alternative method of diagnosis when there is a lack of time or expertise for assessment of Gram-stained smears (Ison and Hay, 2002).

Spiegel, Amsel and Holmes considered three diagnostic techniques for thethe diagnosis of bacterial vaginosis - Clinical examination, Microbiological examination (culture for Gardnerella vaginalis) and Gram's staining. They suggest after their study that Gramstained smear method is the easiest way for diagnosing bacterial vaginosis by clinicians and laboratorians (Carol et al., 1983).

In the years, diagnosis of bacterial vaginosis has seen frequent upgrading of methods, from clinical presentation to gas-liquid chromatography (GLC) and thin-layer chromatography. According to the study conducted by Rotimi and coworkers estimating the number of Gardnerella and Lactobacillus morphotypes in a Gram-stained smear of vaginal discharge, facilitates the diagnosis of bacterial vaginosis for clinicians with minimum need for confirmation by culture, particularly in a third world setting with fewer or no laboratory facilities. This study highlights the presence of clue cells as a diagnostic criteria for labelling patients as bacterial vaginosis positive (Rotimi et al., 1991).

Comparison of methods for diagnosing Bacterial Vaginosis was performed by Krohn,et. Al to determine the laboratory method that best predicted bacterial vaginosis. The methods compared were - Gardnerella vaginalis culture, Gramstained vaginal smears and gas-liquid chromatography.

It was concluded by the above study that the order of -

Sensitivity: Gardnerella vaginalis culture > Gas-liquid chromatography = Gram-stained smears

Specificity: Gram - stained vaginal smears > Gas-liquid chromatography = Gardnerella vaginalis culture (Marijane et al., 1989).

Culture of Gardnerella vaginalis is a challenge to microbiologists as isolating a pure strain is extremely tedious. Because of the relative difficulty of isolating

Gardnerella vaginalis which was attemped by Ison and Dawson, it was concluded that a presumptive diagnosis is often made on the microscopy of wet and Gram-stained preparations of vaginal discharge, looking for clue cells and short Gram Negative bacilli (Ison et al., 1982).

Bacterial vaginosis plays are role in patients with HIV. A study performed by Dora Warren et al., reports an increased risk of bacterial vaginosis in women with HIV infection. They also state that candida is protective against bacterial vaginosis (Dora Warren et al., 2001). Research performed in the Indian setup by 
Hemalatha et al., concluded that determination of vaginal $\mathrm{pH}$ for the diagnosis of bacterial vaginosis is relatively sensitive but less specific. They suggest use of $\mathrm{pH}$ glove and $\mathrm{pH}$ strip as suitable for screening women with bacterial vaginosis on out-patient basis (Hemalatha et al., 2013).

Prevalence of bacterial vaginosis among women in Delhi was studied by P. Bhalla and co-workers showed an association between bacterial vaginosis and other laboratory confirmed sexually transmitted infections (STI's). They also stated in their study that all women with Vaginaltrichomoniasis were found to have bacterial vaginosis (Bhalla et al., 2007).

The main aim and objectives of this study to identify bacterial vaginosis in women presenting with white discharge per vagina. And also to test the efficacy of Gram's stain as an outpatient investigation in the diagnosis of bacterial vaginosis.

Inclusion Criteria: All married women presenting to the out patient department of obstetrics and gynaecology with complaints of white discharge per vagina.

Exclusion Criteria: Un-married and pregnant women.

\section{Materials and Methods}

Study design: Prospective study.

Study setting: Out patient Department of Obstetrics and Gynaecology in Mandya Institute of Medical Sciences.

Study group: All married women coming to the obstetrics and gynaecology out patient with complaints of white discharge per vagina.

Procedure: The study was started after taking approval of the Ethical Committee of the institution. Women coming to the out patient department of Obstetrics and Gynaecology Department with complaints of white discharge per vagina were approached, explained about the purpose of the study and informed consent was taken. A non-lubricated Sim's speculum was inserted into the vagina after keeping the patient in dorsal position. An anterior vaginal wall retractor was used to retract the anterior vaginal wall. A high vaginal swab was taken using a sterile swab supplied by the Department of Microbiology. A smear was prepared for Gram's staining and culture plates, both blood agar and Macconkey's agar were inoculated and incubated.

Grading - Nugent's method is based on counting bacterial morphotypes present on Gram stain of vaginal discharge.

Grade I (normal flora), Lactobacillus morphotype only. $\square$ Grade II (intermediate flora), reduced Lactobacillus morphotype with mixed bacterial morphotypes. $\square$ Grade III (BV), mixed bacterial morphotypes with few or absent Lactobacillus morphotypes. $\square$ Grade IV, epithelial cells covered with Gram positive cocci only.

Score Lactobacillus morphotypes

Gardnerella and Bacteroides spp. Morphotypes

Curved gram-variable rods

$04+0013+1+1+$ or $2+22+2+3+$ or $4+3$ $1+3+404+$

The values obtained according to the grading are scored as shown in the table. The total sum is obtained with the sum of partial scores.

Culture was performed in the department of Microbiology.

The swabs collected were streaked onto Blood agar (BA) and Mac-conkey (MA) agar plates. Post streaking they were incubated at $37^{\circ} \mathrm{C}$ for 
24 hours and reported. Plan of Analysis/ Statistical tools - Data was entered on excel sheet and analysed by EPI_INFO software.

\section{Results and Discussion}

Incidence of bacterial vaginosis by Nugent's criteria

Out of the total 70 samples collected 25(36\%) were positive for bacterial vaginosis and 45(64\%) were negative (Figure 1).

Incidence of bacterial vaginosis in different age groups

Highest incidence was seen in the age group 31 to 40 .

Significance of epithelial cells in bacterial vaginosis

Most of the women who were bacterial vaginosis positive showed an epithelial cell count of $<10$.

Significance of pus cells in bacterial vaginosis

Bacterial vaginosis usually shows a lack of pus cells in the vagina.

Number of lactobacilli in vaginal flora in a case of bacterial vaginosis

Number of lactobacilli is NIL in about $94 \%$ of the bacterial vaginosis positive cases. As the number of lactobacilli increase the incidence of bacterial vaginosis falls drastically.

\section{Role of gram variable bacilli in bacterial vaginosis}

Gram variable bacilli are Gardnerella vaginalis. Presence of $>10$ organisms per oil immersion field shows $100 \%$ result.
Role of Gram negative curved bacilli in bacterial vaginosis (Mobiluncus spp.)

Gram Negative curved bacilli $>10$ shows about $80 \%$ (21 out of 25) of bacterial vaginosis positive cases.

\section{Nugent's score}

A Nugent's score of $>5$ shows $100 \%$ correlation with bacterial vaginosis

Conclusion drawn based on growth shown in culture media

The pie chart represents the presence of various micro-organisms based on the culture report.

Sample of normal vaginal study. It can be taken as a scale to compare other infections.

A case of co-infection of bacterial vaginosis and Staphylococcus aureus (A gram positive cocci). Presence of clue cells indicates that it is a case of bacterial vaginosis. Other factors indicating bacterial vaginosis are Gram variable bacilli (GVB) count of 100 and presence of 40 Gram Negative bacilli (GNB) per oil immersion field. Absence of lactobacilli is another addition to the list of factors favouring bacterial vaginosis. Presence of a significantly high number of pus cells indicates a co-infection which is confirmed to be of Staphylococcus aureus by culturing and shown in Figure 9. Gram Negative bacilli (Escherichia coli, Klebsiella pneumonia, Gram negative non-fermenters) infection presents under the microscope as presence of pus cells, Gram Negative bacilli and absence of clue cell. Presence of an almost normal number of lactobacilli is indicative of an absence of bacterial vaginosis (Figure 10).

Staphylococcal infection encountered in the vagina shows presence of pus cells and 
epithelial cells. There is a considerable decrease in the number of lactobacilli among the vaginal flora (Figure 11).

Bacterial vaginosis with co-infection of candida shows a picture similar to that of BV (clue cells) and budding Gram positive yeast cells with the presence of pseudo-hyphae under oil immersion field (Figure 12).

This is a case of pure bacterial vaginosis infection. The values are typical of BV with minimal lactobacilli in the vagina and associated rise in the gram variable and Gram Negative curved bacilli. Presence of clue cells is another classic feature of bacterial vaginosis (Figure 13). Candidial infection of the vagina is another common infection which presents under the microscope as presence of pseudohyphae with Grampositive budding yeast cells. Absence of clue cells and Gram variable bacilli differentiates it from BV (Figure 14).

In culture, Staphylococcus aureus was the predominant organism isolated (9) among gram positive organisms and E.coli was predominant among gram negative organisms (7).

Direct microscopic examination of clinical material is often used in the diagnosis of bacterial vaginosis.

In this study, we have evaluated the Gram's stain, standard clinical and microbiological (culture) criteria.

In the present study the incidence of BV was $36 \%$. This correlates with other Indian studies performed by (Bhalla et al., 2007) which gave a result of $32.8 \%$ incidence of bacterial vaginosis.

A study by (Hemalatha et al., 2013) showed the mean age of incidence of bacterial vaginosis as $29+/-4.8$. Our results are in agreement, with maximum incidence of bacterial vaginosis between the age groups 31 to 40. The probable reason for this coincidence in results can be attributed to the population chosen which mostly consisted of women belonging to reproductive age group, which incidentally is the sexually active group.

As shown in figures 3 and 4 a decrease in the number of epithelial cells are consistent with the positive cases of bacterial vaginosis. As told in (Jeffecoat's) about microscopy of vaginal secretions, presence of leucocytes is not significant in BV.

Fig.1 Diagnosis of Bacterial vaginosis by Gram's stain

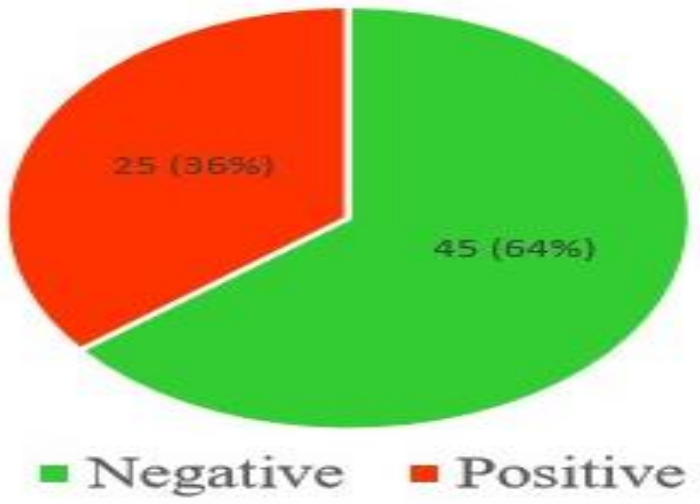


Fig.2 Incidence of bacterial vaginosis among women of different age groups

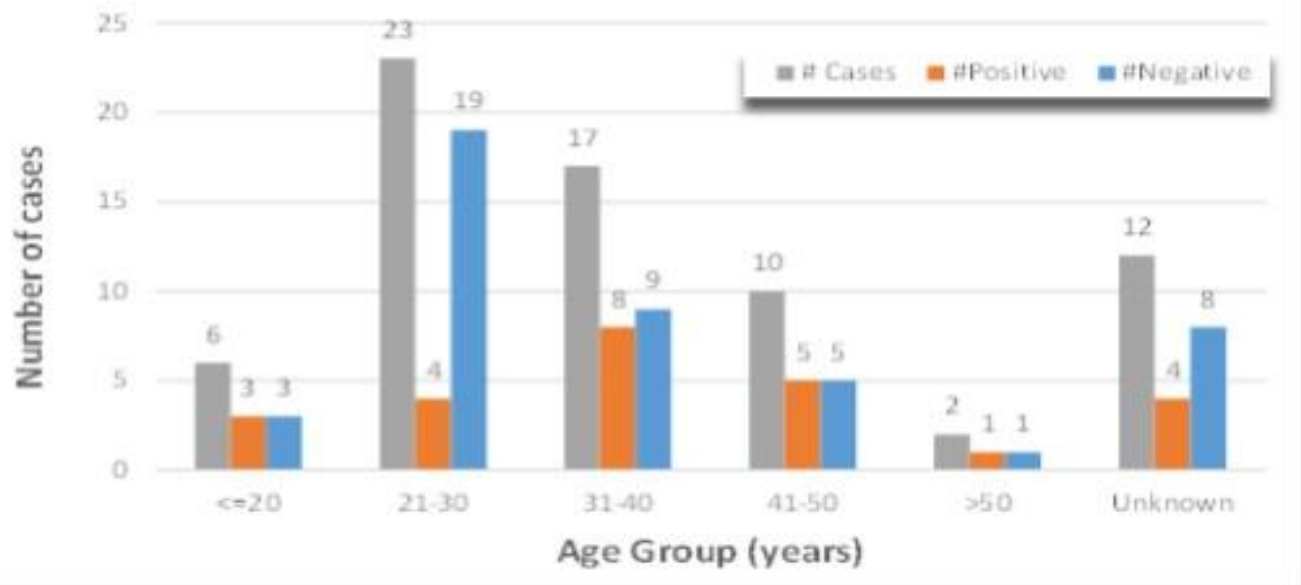

Fig.3 Epithelial cells in bacterial vaginosis

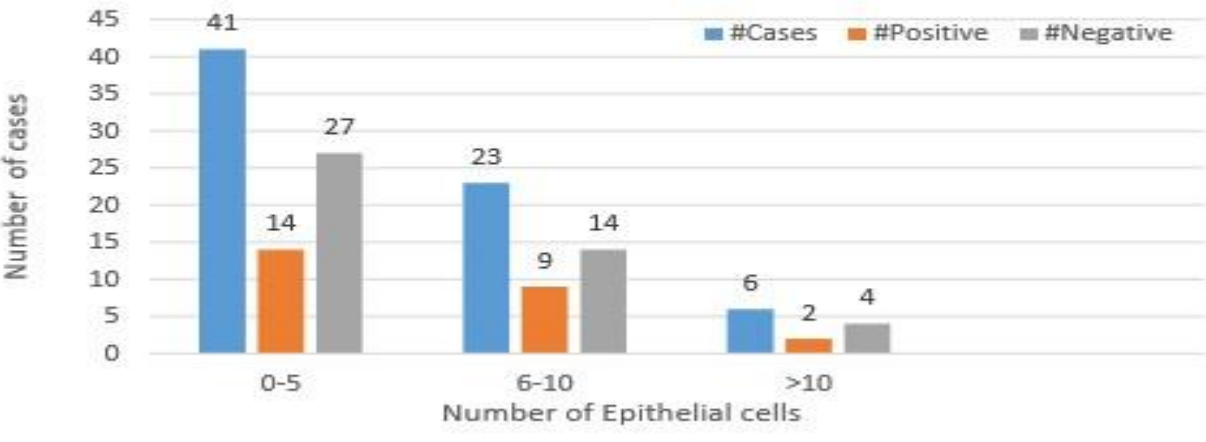

Fig.4 Association of pus cells to bacterial vaginosis

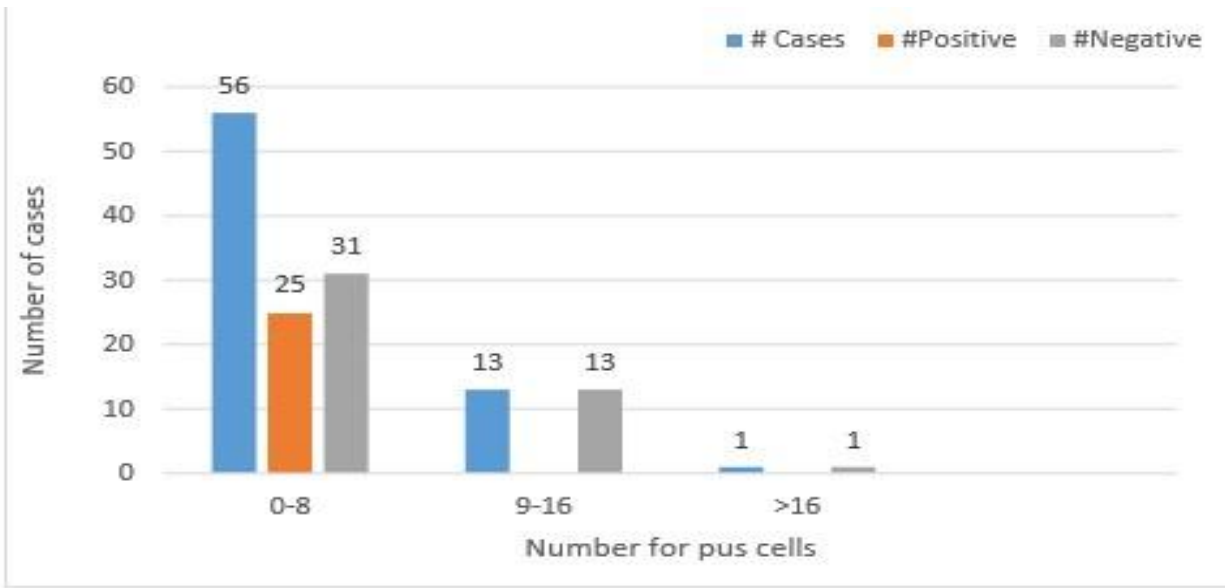


Fig.5 Number of lactobacilli in vaginal flora in a case of bacterial vaginosis

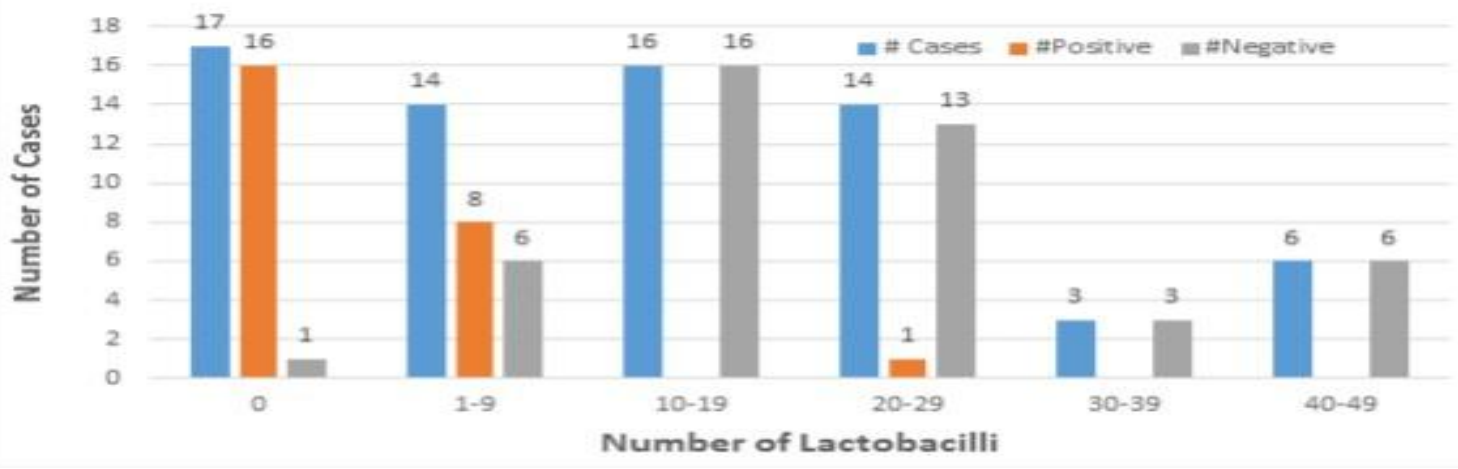

Fig.6 Gram variable bacilli in bacterial vaginosis

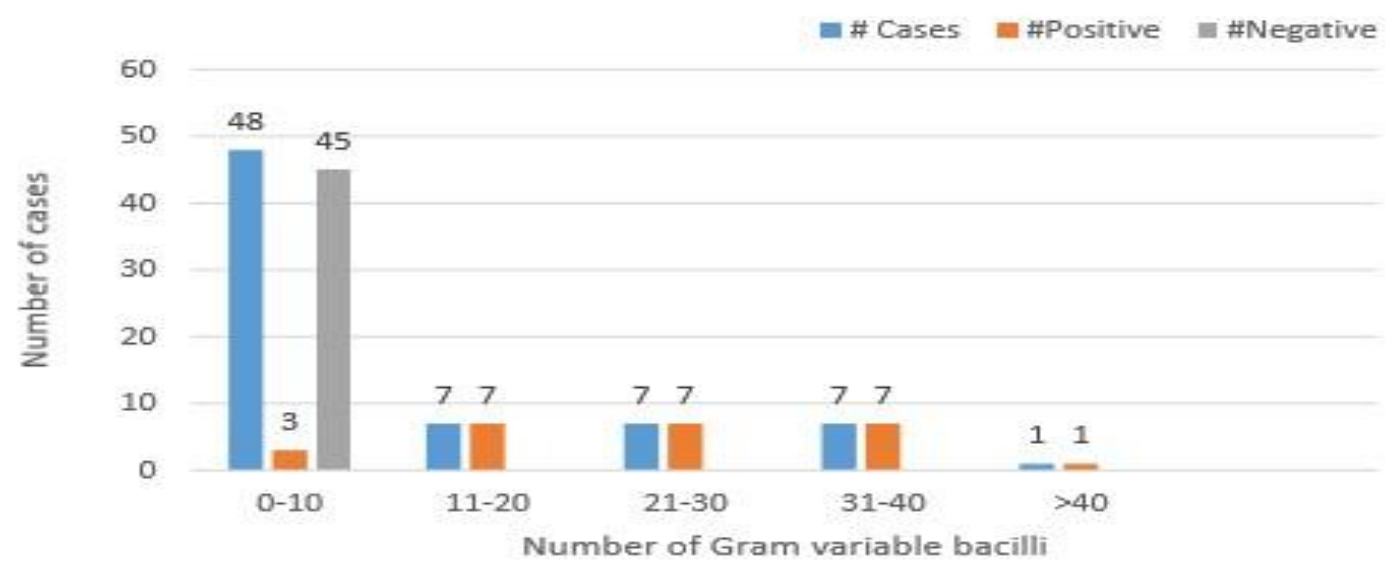

Fig.7 Gram Negative curved bacilli in bacterial vaginosis

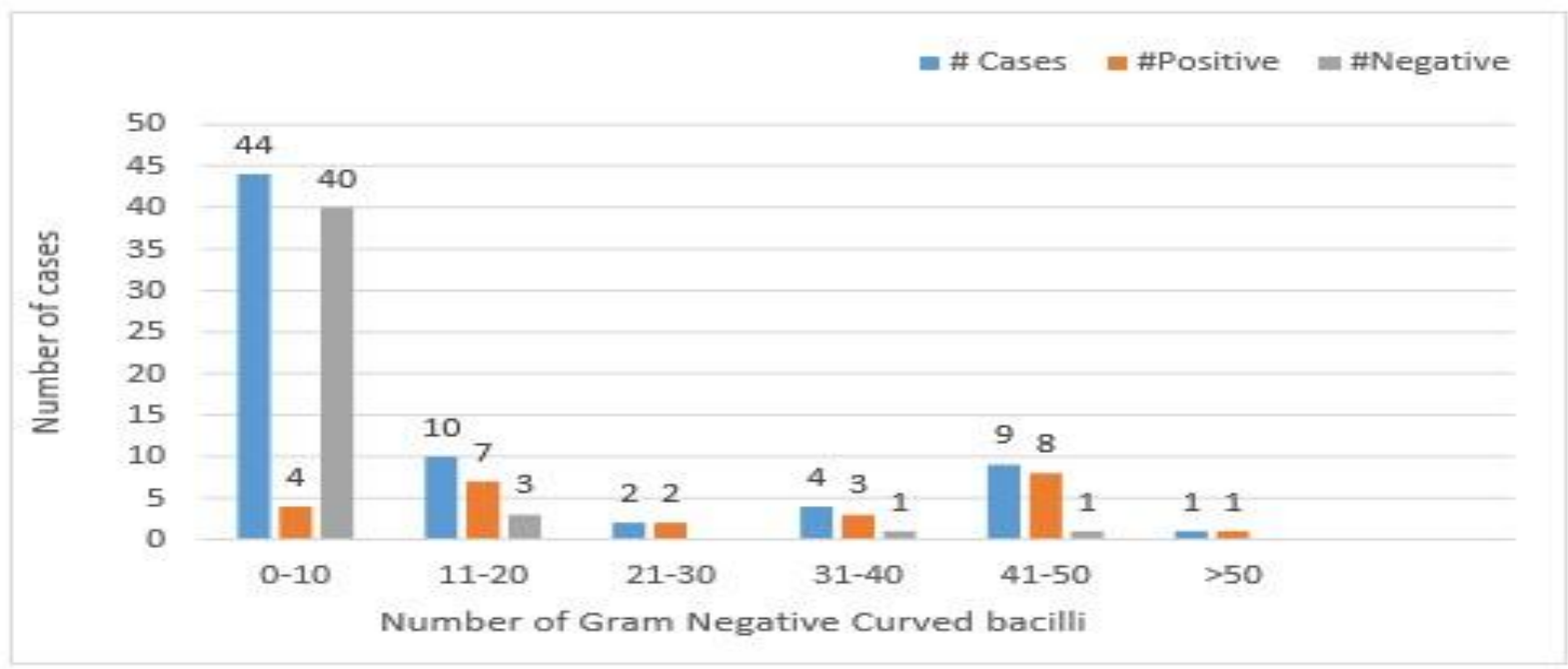


Fig.8 Relationship between bacterial vaginosis and Nugent's score

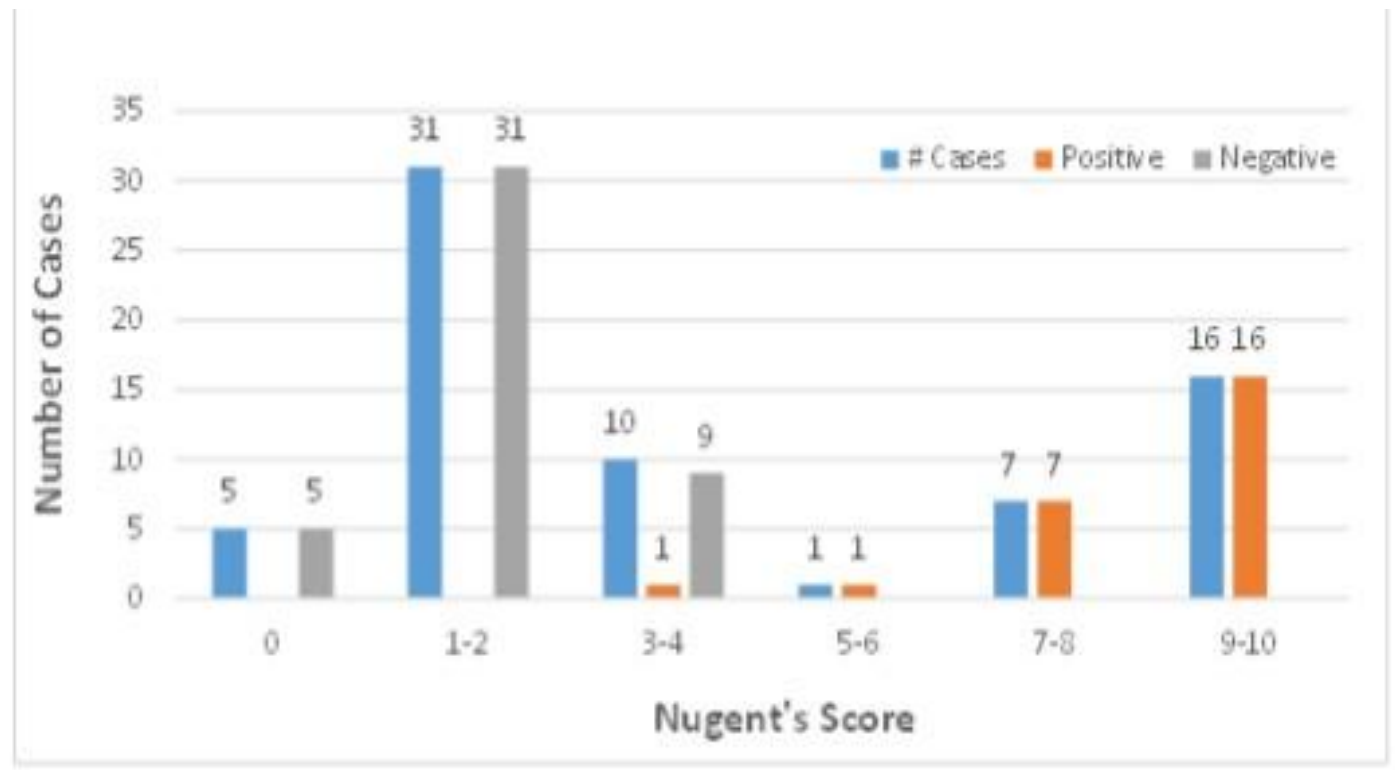

Fig.9 Pie chart representing the presence of various micro-organisms based on culture report

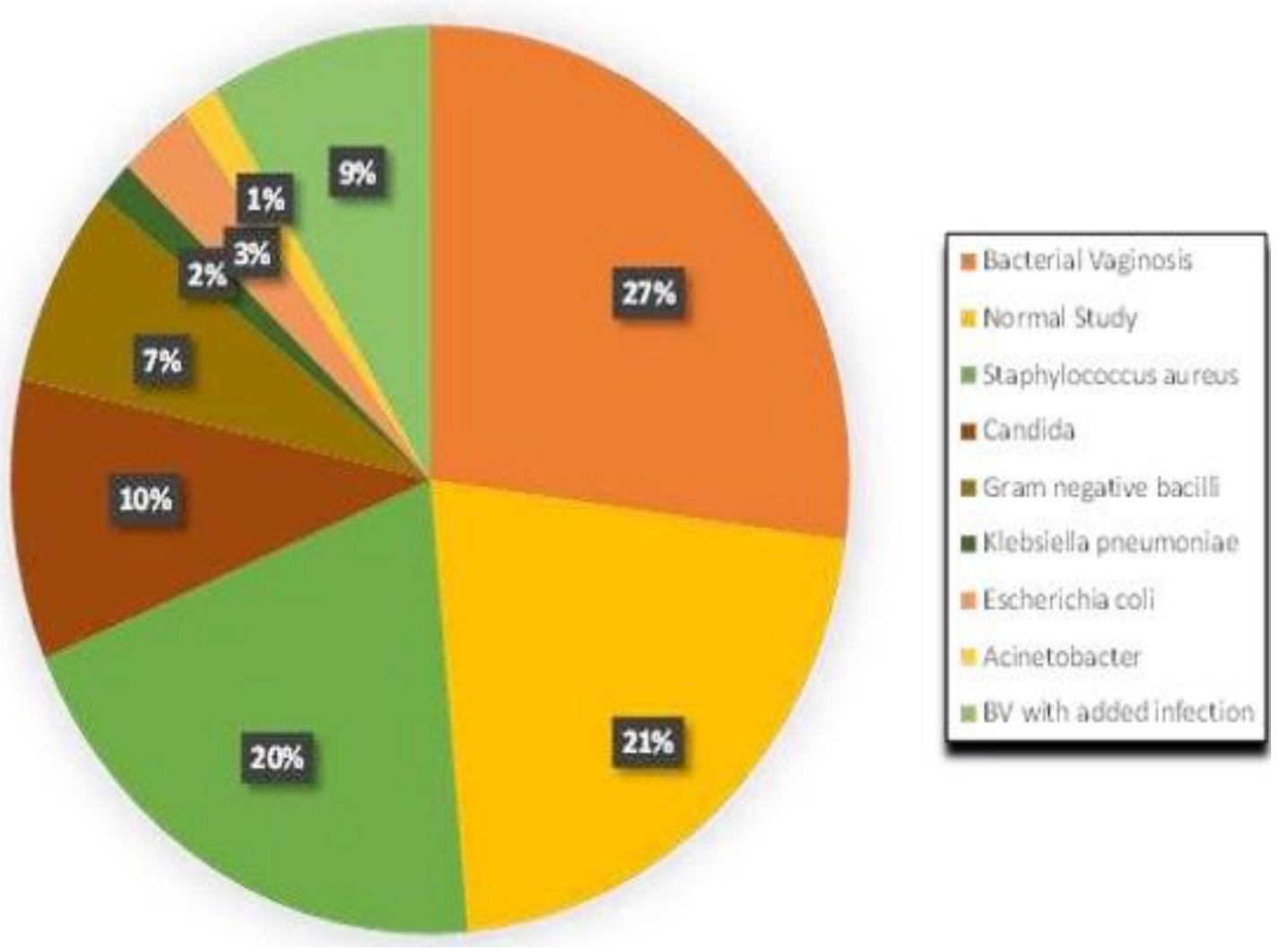


Fig.10 Bacterial vaginosis with Staphylococcus co-infection

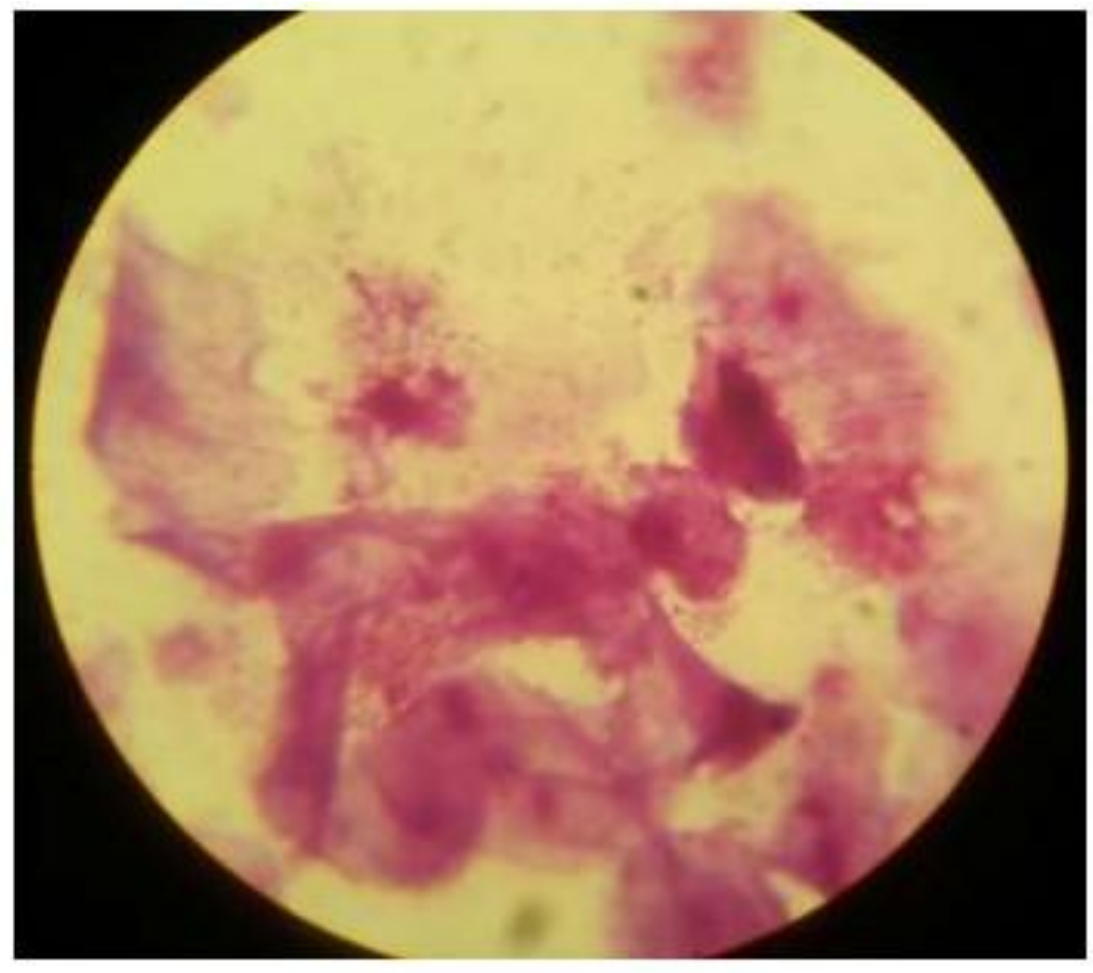

Fig.11 Gram Negative bacilli infection

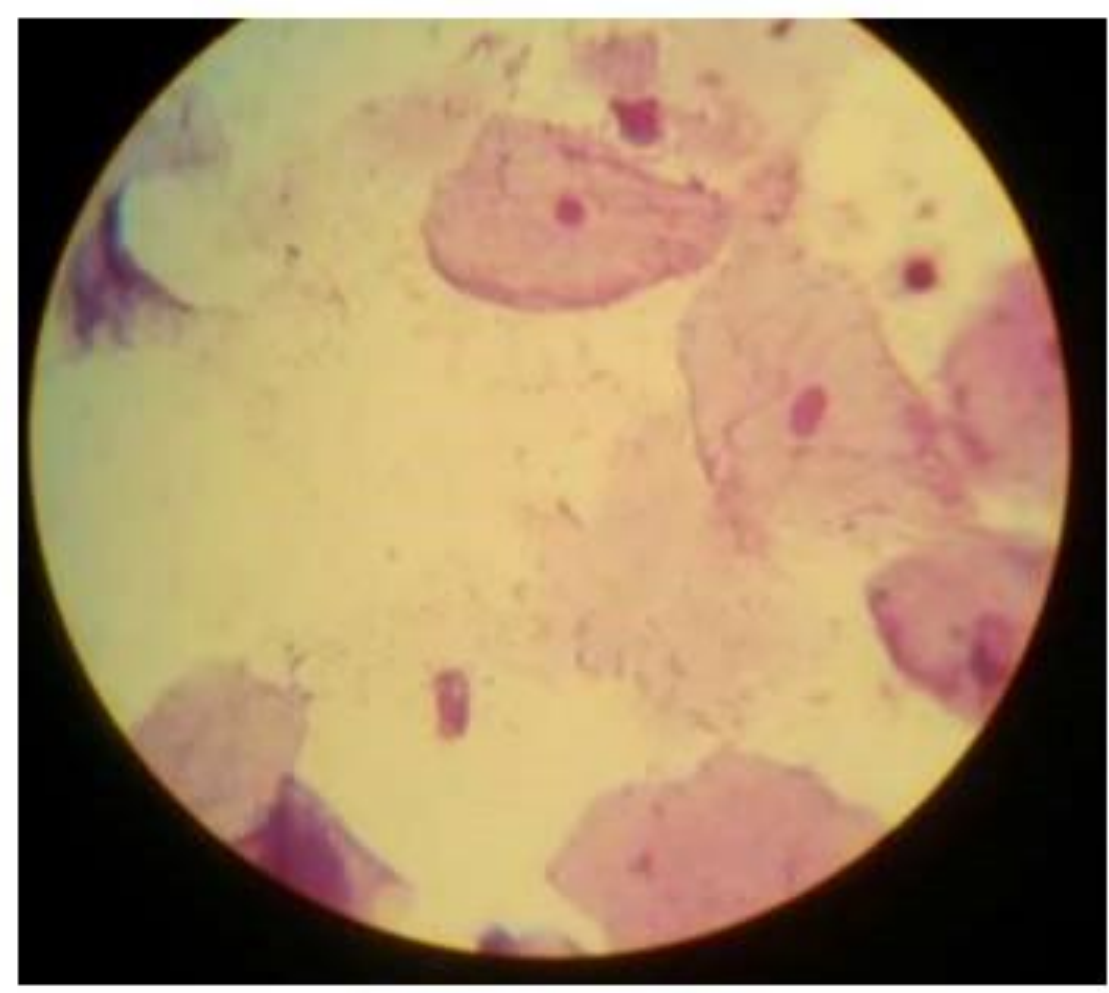


Fig.12 Mixed infection with Gram positive cocci and Gram negative bacilli

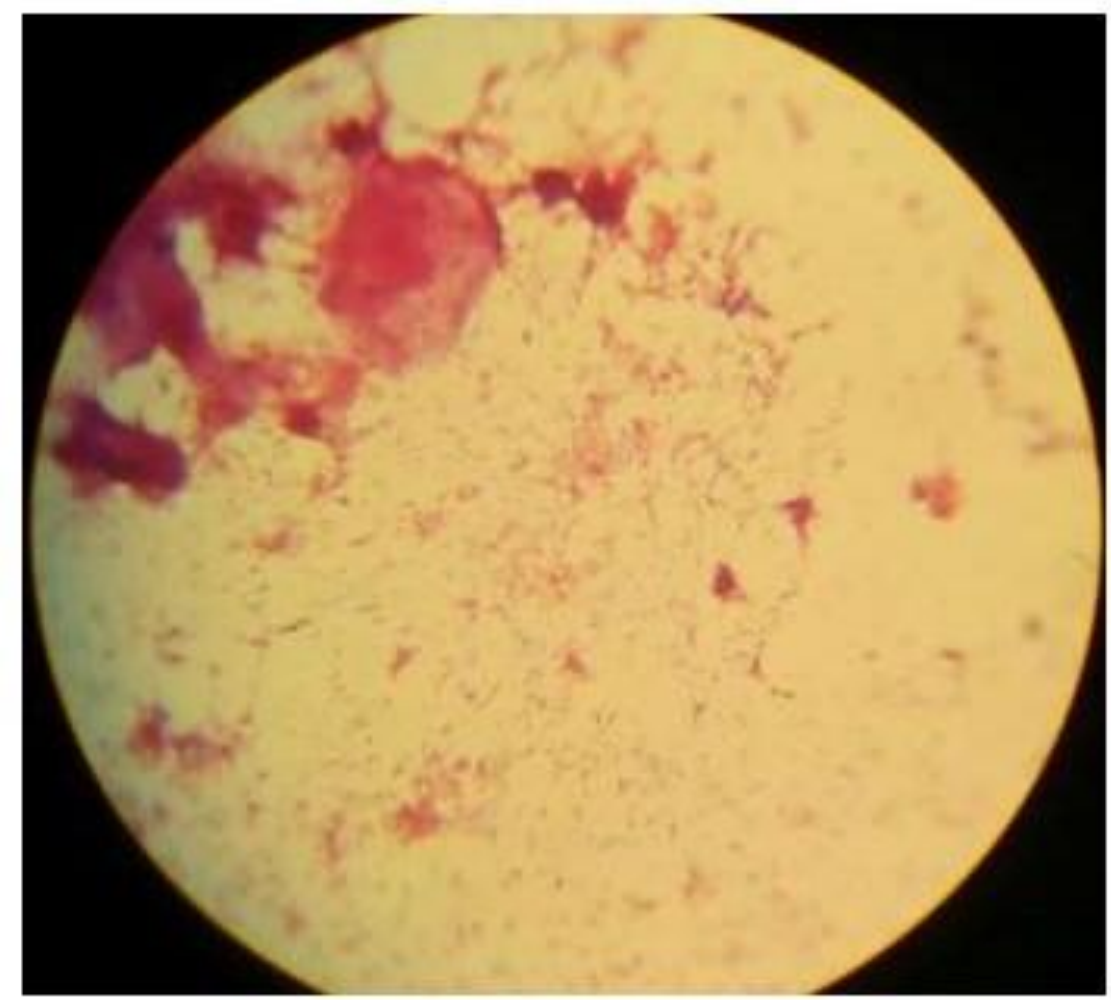

Fig.13 Bacterial vaginosis with co-infection of candida

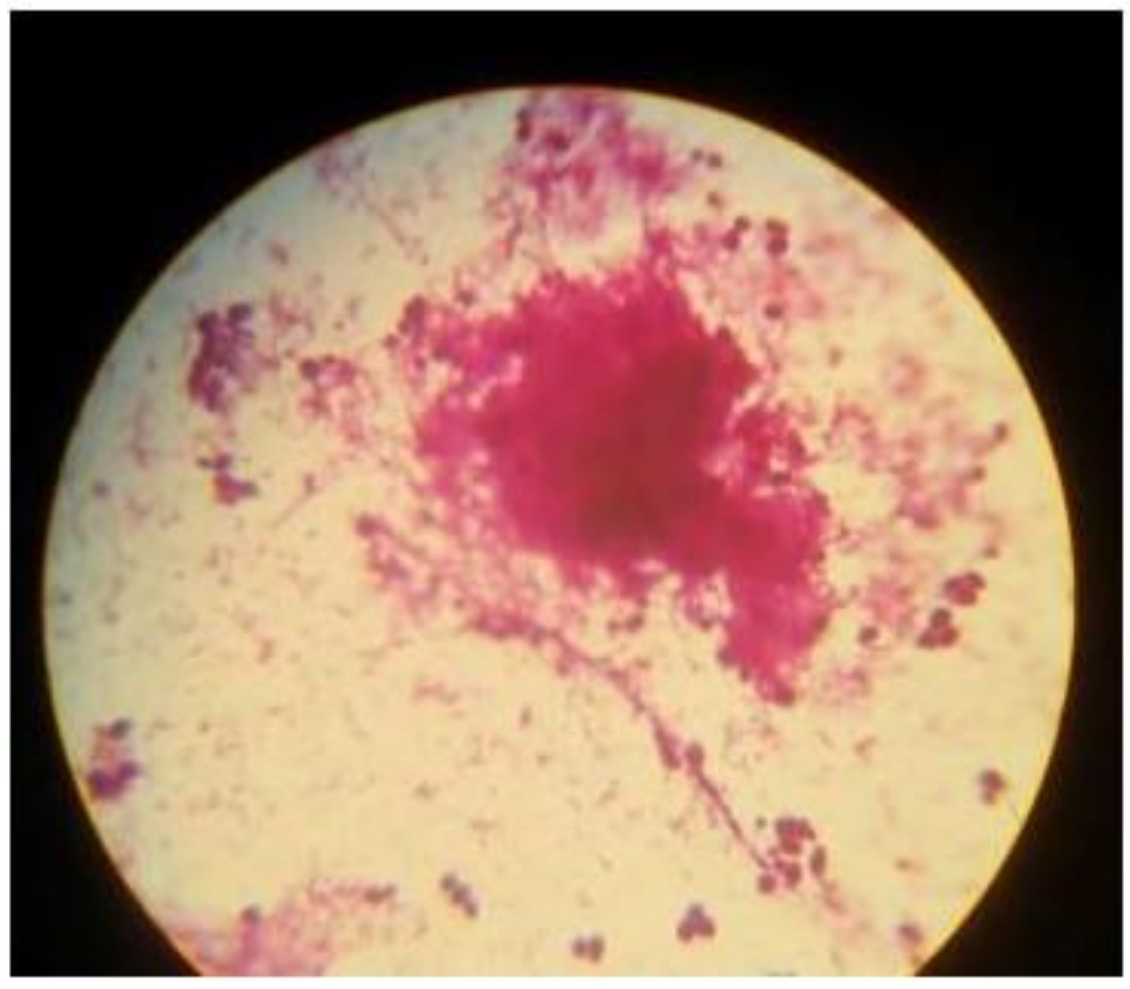


Fig.14 Bacterial vaginosis; presence of clue cells is characteristic

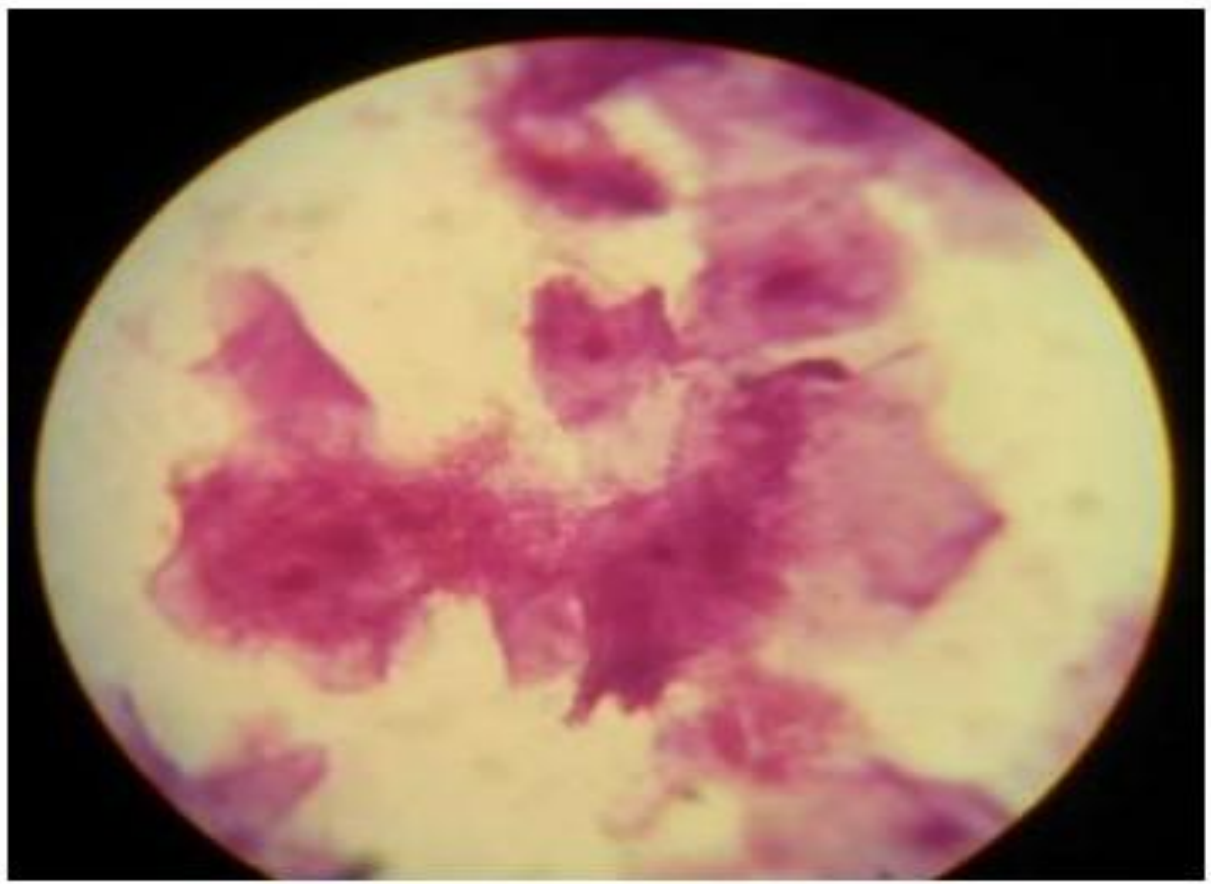

Fig.15 Candida showing pseudohyphae

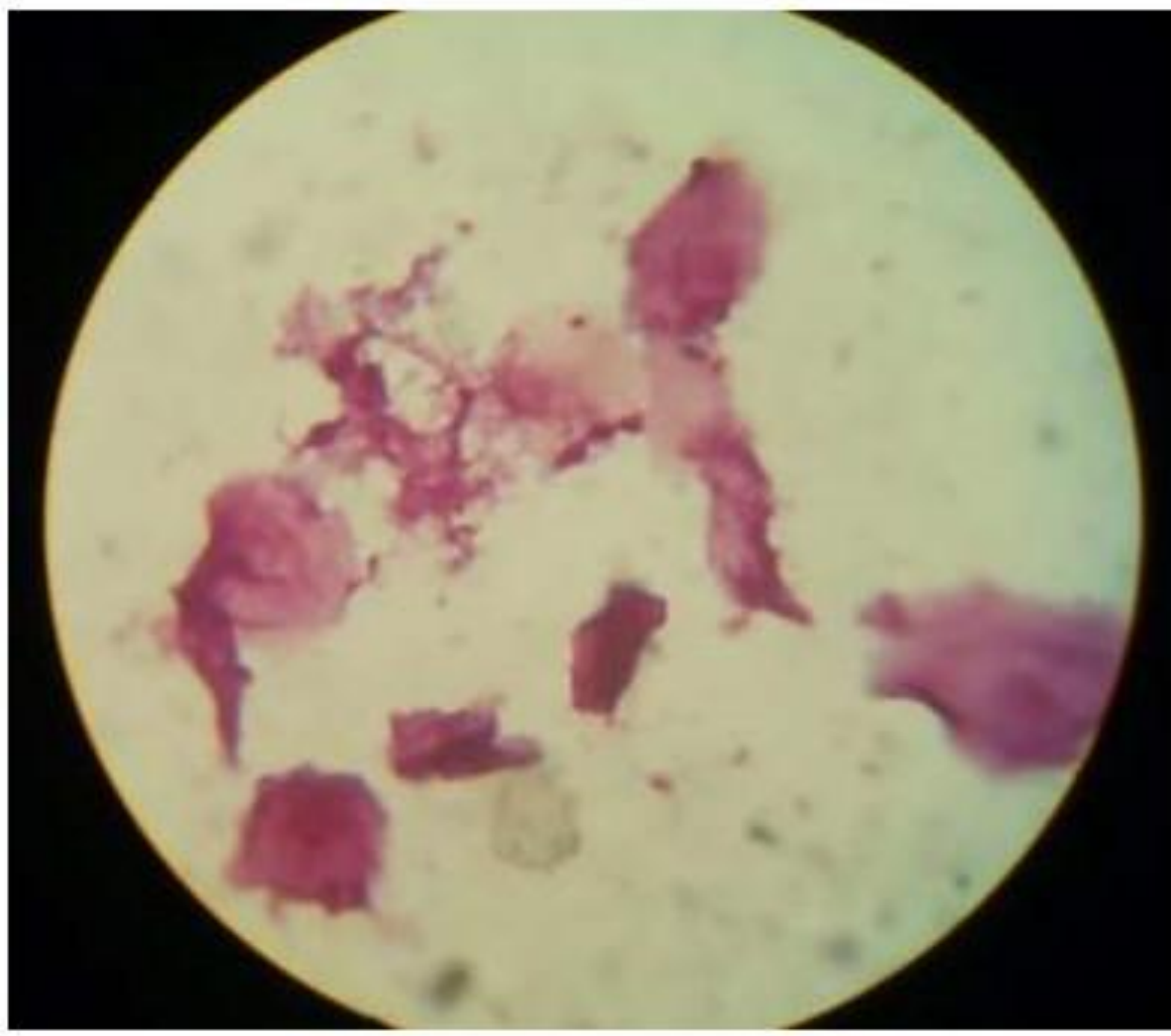


Fig.16 Lactose-fermenting colonies

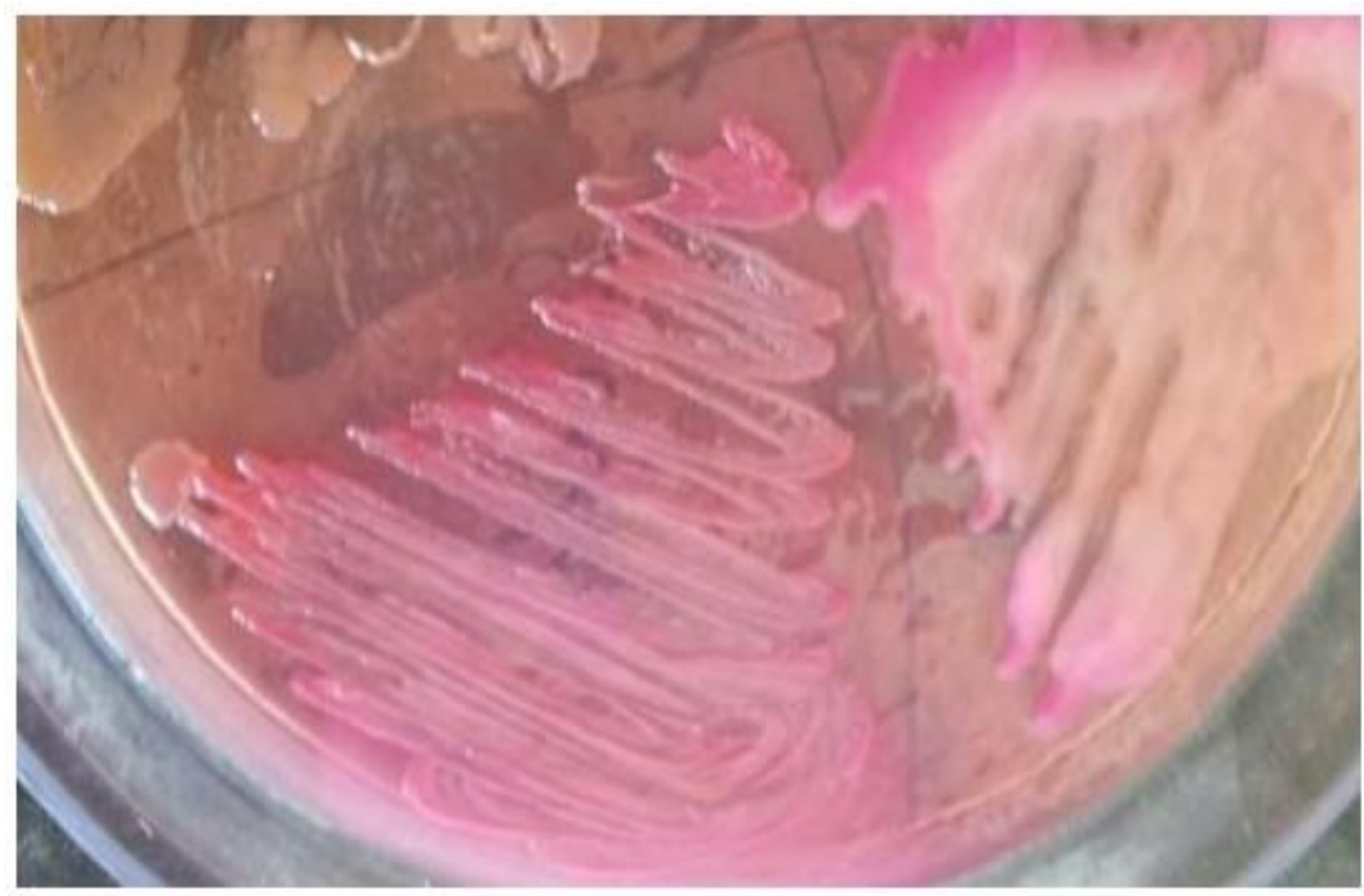

Fig.17 Non-lactose fermenting colonies

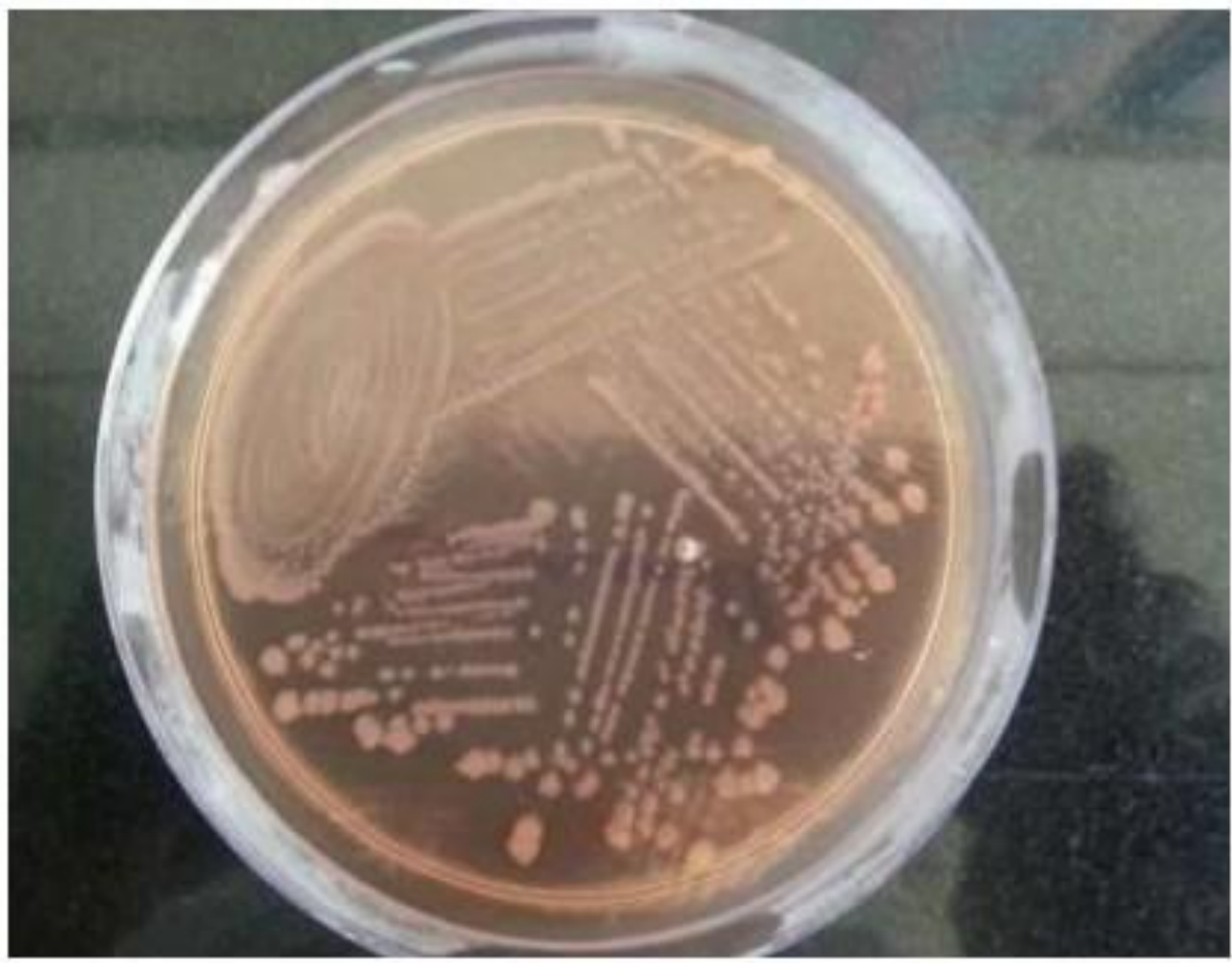


Fig.18 Growth of Candida on blood agar

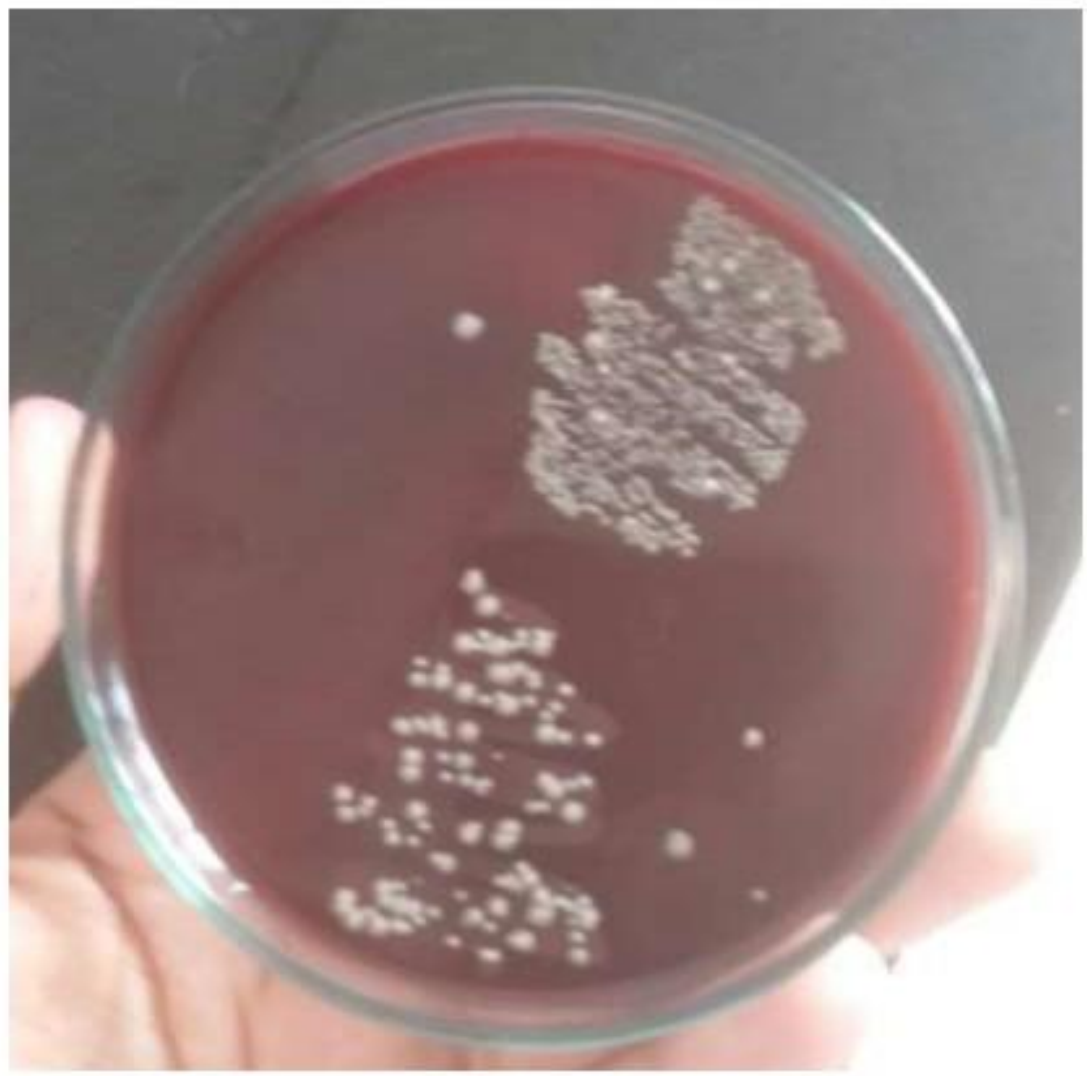

Scoring -

\begin{tabular}{|l|l|l|l|}
\hline Score & $\begin{array}{l}\text { Lactobacillus } \\
\text { morphotypes }\end{array}$ & $\begin{array}{l}\text { Gardnerella and } \\
\text { Bacteroides spp. } \\
\text { Morphotypes }\end{array}$ & $\begin{array}{l}\text { Curved gram-variable } \\
\text { rods }\end{array}$ \\
\hline 0 & $4+$ & 0 & 0 \\
\hline 1 & $3+$ & $1+$ & $1+$ or $2+$ \\
\hline 2 & $2+$ & $2+$ & $3+$ or $4+$ \\
\hline 3 & $1+$ & $3+$ & \\
\hline 4 & 0 & $4+$ & \\
\hline
\end{tabular}




\section{Correlation of Nugent's criteria with culture report}

\begin{tabular}{|c|c|c|c|c|c|c|c|c|c|}
\hline $\begin{array}{l}\text { Sample } \\
\text { No. }\end{array}$ & \begin{tabular}{|c|}
$\begin{array}{c}\text { Epithelial } \\
\text { cells }\end{array}$ \\
\end{tabular} & $\begin{array}{l}\text { Clue } \\
\text { cells }\end{array}$ & $\begin{array}{l}\text { Pus } \\
\text { cells }\end{array}$ & Lactobacilli & GVB & GNB & Score & Culture Report & $\begin{array}{c}\text { Gram's } \\
\text { stain }\end{array}$ \\
\hline 1 & 15 & 0 & 0 & 40 & 0 & 0 & 0 & $\begin{array}{l}\text { Normal Study } \\
\text { (Lactobacilli grown) }\end{array}$ & BV-Negative \\
\hline 2 & 12 & 10 & 0 & 0 & 100 & 40 & 10 & Staphylococcus aureus & BV-Positive \\
\hline 3 & 2 & 0 & 10 & 12 & 0 & 20 & 3 & $\begin{array}{l}\text { Gram negative non- } \\
\text { fermenter }\end{array}$ & BV-Negative \\
\hline 4 & 8 & 0 & 8 & 4 & 1 & 0 & 3 & Staphylococcus aureus & BV-Negative \\
\hline 5 & 7 & 5 & 2 & 0 & 20 & 50 & 9 & Candida & BV-Positive \\
\hline 6 & 5 & 5 & 3 & 0 & 30 & 50 & 9 & No growth & BV-Positive \\
\hline 7 & 4 & 0 & 2 & 15 & 0 & 50 & 3 & Candida & BV-Negative \\
\hline
\end{tabular}

Table.1 Organisms isolated in culture

\begin{tabular}{|l|c|}
\hline ORGANISM & NO ISOLATED \\
\hline E.coli & 05 \\
\hline Klebsiella pneumoniae & 01 \\
\hline Bacterial vaginosis & 19 \\
\hline Staphylococcus aureus & 09 \\
\hline Candida & 07 \\
\hline Pseudomonas aeruginosa & 01 \\
\hline Acinetobacter & 02 \\
\hline Proteus mirabilis & 01 \\
\hline Mixed infections & 04 \\
\hline
\end{tabular}

Table.2 Organisms isolated in combination

\begin{tabular}{|l|l|}
\hline ORGANISM COMBINATION & NO ISOLATED \\
\hline Bacterial vaginosis + Candida & 02 \\
\hline Bacterial vaginosis +E.coli & 01 \\
\hline Cons + Candida & 01 \\
\hline
\end{tabular}




\section{Antibiogram of organisms isolated}

\begin{tabular}{|c|c|c|c|c|c|c|c|c|c|c|c|c|c|c|c|c|c|c|c|c|c|c|c|c|c|c|c|}
\hline \multirow{2}{*}{\multicolumn{2}{|c|}{$\begin{array}{l}\text { Organism } \\
\text { E.coli }\end{array}$}} & \multicolumn{17}{|c|}{ Sensitive } & \multicolumn{9}{|c|}{ Resistant } \\
\hline & & \multirow[b]{2}{*}{ IPM } & \multirow[b]{2}{*}{ PI } & \multirow[b]{2}{*}{$\mathrm{CAC}$} & \multirow[b]{2}{*}{$\mathrm{AK}$} & \multirow[b]{2}{*}{ GEN } & \multirow[b]{2}{*}{ OF } & \multirow[b]{2}{*}{ PIT } & \multirow[b]{2}{*}{ CTX } & \multirow[b]{2}{*}{ CEC } & \multirow[b]{2}{*}{ TGC } & \multirow[b]{2}{*}{ CTR } & \multirow[b]{2}{*}{-} & \multirow[b]{2}{*}{-} & \multirow[b]{2}{*}{-} & \multirow[b]{2}{*}{-} & \multirow[b]{2}{*}{-} & \multirow[b]{2}{*}{-} & \multirow[b]{2}{*}{$\mathrm{CX}$} & & & & & & & & \\
\hline 1 & BV-01 & & & & & & & & & & & & & & & & & & & AMF & $\mathrm{CA}$ & & MRI & & $\mathrm{TE}$ & - & . \\
\hline 2 & BV06 & CAC & IPM & PI & AMP & GEN & $\mathrm{OF}$ & PIT & TGC & - & - & - & - & - & - & - & - & - & $\mathrm{AK}$ & $\mathrm{CX}$ & $\mathrm{TE}$ & & MRI & & CAZ & & \\
\hline 3 & BV-21 & $\mathrm{AK}$ & PI & CX & PIT & ETP & $\mathrm{TE}$ & AMP & CTX & CAZ & CEC & TGC & $\mathrm{OF}$ & IPM & GEN & CTR & CAC & MRP & - & - & - & & - & - & - & - & - \\
\hline 4 & BV29 & CAC & CAZ & IPM & PIT & GEN & CTX & CEC & TGC & OF & $\mathrm{CX}$ & CTR & - & - & - & - & - & - & PI & AMF & $\mathrm{AK}$ & & $\mathrm{TE}$ & & MRP & & 10 \\
\hline 5 & BV43 & MRP & CAC & IPM & GEN & CEC & $\mathrm{AK}$ & PIT & TGC & PI & $\mathrm{OF}$ & CTR & $\mathrm{CX}$ & TE & - & - & - & - & CTX & CAZ & - & & - & . & - & - & - \\
\hline & $\begin{array}{l}\text { siella } \\
\text { moniae }\end{array}$ & & & & & & & & & & & & & & & & & & & & & & & & & & \\
\hline 1 & BV35 & MRP & TGC & PIT & CEC & CAC & $\mathrm{AK}$ & PI & $\mathrm{OF}$ & IPM & $\mathrm{TE}$ & $\mathrm{CX}$ & - & - & - & - & - & - & CTX & CAZ & Al & & GEN & & - & - & \\
\hline & $\begin{array}{l}\text { hylococc } \\
\text { eus }\end{array}$ & & & & & & & & & & & & & & & & & & & & & & & & & & \\
\hline 1 & BV-04 & LZ & CIP & $\mathrm{CD}$ & $\mathrm{C}$ & COT & VA & LE & - & - & - & - & - & - & - & - & - & - & OX & CX & $\mathrm{P}$ & E & & - & - & - & - \\
\hline 2 & BV13 & LZ & VA & E & COT & - & - & - & - & - & - & - & - & - & - & - & - & - & CX & $\mathrm{C}$ & $\mathrm{CD}$ & CII & & $\mathrm{P}$ & & OX & LE \\
\hline 3 & BV22 & LZ & $\mathrm{C}$ & COT & VA & LE & - & - & - & - & - & - & - & - & - & - & - & - & E & $\mathrm{CD}$ & CIP & $\mathrm{P}$ & & OX & & CX & - \\
\hline 4 & BV25 & VA & $\mathrm{P}$ & $\mathrm{CX}$ & OX & $\mathrm{LZ}$ & LE & COT & - & - & - & - & - & - & - & - & - & - & CIP & $\mathrm{CD}$ & E & $\mathrm{C}$ & & - & - & - & - \\
\hline 5 & BV31 & GEN & E & COT & LZ & VA & - & - & - & - & - & - & - & - & - & - & - & - & OX & CX & $\mathrm{P}$ & $\mathrm{CD}$ & & LE & & CIP & - \\
\hline 6 & BV30 & LZ & E & COT & VA & $\mathrm{CD}$ & - & - & - & - & - & - & - & - & - & - & - & - & OX & CX & $\mathrm{P}$ & GE & & LE & & CIP & - \\
\hline 7 & BV10 & LZ & $\mathrm{E}$ & $\mathrm{CD}$ & CX & OX & LE & $\mathrm{C}$ & COT & VA & GEN & CIP & $\mathrm{P}$ & - & - & - & - & - & - & - & - & - & & - & - & - & - \\
\hline 8 & BV12 & LZ & GEN & E & $\mathrm{CD}$ & VA & OX & CIP & CX & LE & COT & $\mathrm{P}$ & - & - & - & - & - & - & $\mathrm{C}$ & - & - & - & & - & - & - & - \\
\hline 9 & BV49 & CIP & C & CX & $\mathrm{LZ}$ & VA & LE & GEN & - & - & - & - & - & - & - & - & - & - & $\mathrm{E}$ & $\mathrm{CD}$ & OX & $\mathrm{P}$ & & - & - & - & - \\
\hline & & & & & & & & & & & & & & & & & & & & & & & & & & & \\
\hline 1 & BV14 & $\mathbf{L Z}$ & VA & COT & OX & $\mathrm{CX}$ & GEN & $\mathbf{P}$ & LE & - & - & - & - & - & - & - & - & - & $\mathbf{E}$ & CD & CIP & - & & - & - & & - \\
\hline & $\begin{array}{l}\text { domonas } \\
\text { ginosa }\end{array}$ & & & & & & & & & & & & & & & & & & & & & & & & & & \\
\hline 1 & BV43 & $\mathrm{TE}$ & PI & PIT & AK & MRP & GEN & CAZ & PB & $\mathrm{CL}$ & IPM & - & - & - & - & - & - & - & CTX & - & - & - & & - & - & & - \\
\hline 2 & BV48 & IPM & MRP & CAZ & $\mathrm{AK}$ & GEN & PB & $\mathrm{CL}$ & PI & PIT & - & - & - & - & - & - & - & - & CTX & $\mathrm{TE}$ & - & - & & - & - & & - \\
\hline & etobacter & & & & & & & & & & & & & & & & & & & & & & & & & & \\
\hline 1 & BV52 & $\mathrm{AK}$ & GEN & $\mathrm{OF}$ & $\mathrm{TE}$ & IPM & MRP & CIP & & & & & & & & & & & CTX & CTR & CAZ & - & & - & - & & - \\
\hline 2 & BV57 & $\mathrm{AK}$ & GEN & IPM & MRP & - & - & - & - & - & - & - & - & - & - & - & - & - & CTX & CAZ & $\mathrm{TE}$ & OI & $\mathrm{F}$ & CIP & & & \\
\hline & & & & & & & & & & & & & & & & & & & & & & & & & & & \\
\hline 1 & BV59 & $\mathrm{AK}$ & GEN & CPD & IPM & MRP & CX & CIP & CTX & CAZ & $\mathrm{OF}$ & PI & PIT & - & - & - & - & - & - & - & - & - & & - & - & & - \\
\hline
\end{tabular}


In the present study, the decrease in lactobacilli count has shown significant rise in the bacterial vaginosis positive case which is in consonance with the study performed by (Krohn et al.,) which also confirms that, there is decrease in frequency of Lactobacilli spp., among women with bacterial vaginosis. However, another study by Martinez et al., (2) states that Nugent's method helps in making a sub-diagnosis of the disease, due to a low cutoff point and overestimates the relevance of reduced lactobacilli in the diagnosis of the disease.

The study performed, shows a direct relationship of Gram variable bacilli (Gardnerella vaginalis) and Gram Negative curved bacilli (Mobiluncus spp.) to bacterial vaginosis. An increase in the number of Gram variable bacilli and Gram Negative bacilli shows an increase in incidence of bacterial vaginosis (Figure 6).

Spiegel et al., also confirms in his study that Gram variable bacilli and Gram Negative bacilli are among the causative organisms of $\mathrm{BV}$, which is in agreement to our study.

Another study performed by Krohn et al., presents a relationship of Gardnerella vaginalis, Bacteroides spp. to $\mathrm{BV}$ after adjustment for co-infections.

Nugent's method was the tool used for scoring the Gram-stained smears which indicate that a score $>5$ always seemed to be positive for bacterial vaginosis. We proposed to use this method as the inter-center and different microbiologist agreement was better compared to the other existing methods.

This inference is in consonance with the study performed by Nugent (1) where he says the Spiegel criteria for diagnosing BV had only moderate intercenter agreement. Hence Nugent's criteria used bacterial morphotypes to produce a summary score that can be used to assess the degree of alteration in vaginal flora as a continuum.

In the present study, all the samples were subjected to culture on blood agar and Macconkey agar.

Bacterial vaginosis which is about $27 \%$ by Gram's stain showed no growth on culture, followed by cases which were normal about $21 \%$ where lactobacilli were grown producing greyish-green alpha haemolytic colonies, subsequent positions were occupied by Staphylococcus (20\%), Candida (10\%), BV (by Gram's stain) with added infection (9\%), Gram negative non-fermenters (7\%), Escherichia coli (3\%), Klebsiella (2\%) and Acinetobacter (1\%).

Gram's stain and culture helped us to identify co-infection cases, other bacterial and candida infection.

Diagnosis of BV based on clinical criteria and Gram's stain are better than culture.

The present study is in synchrony with Nugent's score for diagnosis of BV.

In symptomatic women, Gram's staining and scoring by Nugent's method has a very high positive predictive value with the diagnosis of BV.

Since, Nugent's score is based on Gram's stain it can be done even in a outpatient setting.

So this is a simple, less expensive and less time-consuming for the diagnosis BV. It can be preserved for later reference/correlation and most reliable.

The study was aimed to investigate the effectiveness of Gram's staining and Nugent's 
scoring as a side lab investigation for the diagnosis of bacterial vaginosis.

For this, women complaining of excessive white discharge per vagina were selected based on the inclusion \& exclusion criteria suggested in the Methodology of the study, for procuring high vaginal swabs. These swabs were Gram's stained and scored by Nugent's method.

Results were tabulated and analysed which shows that $36 \%$ of the study population were suffering from bacterial vaginosis. Out of the $36 \%$, most women belonged to the reproductive age group.

Presence of clue cells (epithelial cells studded with GVB and GNB), absence or decrease in the number of lactobacilli and elevated number of GVB and GNB were the observations under the microscope in all positive cases of BV. Certain co-existing conditions like candidial or Staphylococcal infections were noted in the study.

Hence, to conclude the study favours the use of Gram's stained vaginal smears scored by Nugent's criteria as a side lab investigation in the out-patients where high-end diagnostic techniques are unavailable or un-affordable for the diagnosis of bacterial vaginosis.

\section{Suggestions}

The proposed technique of Gram's stain can be done in all out-patient women coming with symptoms of excessive white discharge per vagina as it is less time consuming, yields accurate results and in-expensive.

Treating the cases by proper evaluation helps overcome the existing trend of antibiotic resistance and also screening of all the suspected cases aids in early treatment and avoiding complications.

\section{Acknowledgement}

This is an ICMR funded and approved project. Our profuse thanks to ICMR for funding this project.

\section{References}

Bhalla P., Rohit Chawla, S. Garg, M.M. Singh, U. Raina, Ruchira Bhalla \& PushpaSodhani Prevalence of bacterial vaginosis among women in Delhi, India Indian J Med Res 125, February 2007, pp 167-172

Bradshaw, C.S., A. N. Morton, S. M. Garland, L. B. Horvath, I. Kuzevska, and C. K. Fairley. Evaluation of a Point-of-Care Test, BVBlue, and Clinical and Laboratory Criteria for Diagnosis of Bacterial Vaginosis. Journal of Clinical Microbiology Mar. 2005, p. 1304-1308 Vol. 43, No. 3

Carol, A. Spiegel, Richard Amsel and King. K. Holmes. Diagnosis of Bacterial Vaginosis by Direct Gram Stain of Vaginal Fluid Journal of Clinical Microbiology. July 1983, P. 170-177 Vol. 18, No. 1

Dora Warren, Robert S. Klein, Jack Sobel, Burney Kieke, Jr, William Brown, Paula Schuman, Jean Anderson, Susan Cu-Uvin, Kenneth Mayer, Denise J. Jamieson, Scott Holmberg, Ann Duerr. A multicenter study of bacterial vaginosis in women with or at risk for human immunodeficiency virus infection Infect Dis ObstetGynecol 2001; 9:133-141

Hemalatha R, Ramalaxmi BA, Swetha E, Balakrishna N, Mastromarino $P$. Evaluation of vaginal $\mathrm{pH}$ for detection of bacterial vaginosis. The Indian Journal of Medical Research. 2013; 138(3):354-359.

Ison, C.A., and $\mathrm{P}$ E Hay. Validation of a 
simplified grading of Gram stained vaginal smears for use in genitourinary medicine clinics Sex Transm Infect 2002; 78:413-415

Ison, C.A., SG Dawson, J. Hilton, GW Csonka, CSF Easmon Comparison of culture and microscopy in the diagnosis of Gardnerella vaginalis infection. J. ClinPathol 1982; 35:550-554

Jeffcoate's Principles of Gynaecology. 7th edition; Page -658 .

Marijane, A. Krohn, Sharon. L. Hillier and David. A. Eschenbach Comparison of Methods for Diagnosing Bacterial Vaginosis among Pegnant Women. Journal of Clinical Microbiology. June 1989, p. 1266-1271 Vol. 27, No. 6

Martinez-Martinez, W., B. Calderon-Badia and L. Cruz-Lage. Comparison of diagnostic methods for bacterial vaginosis. African journal of microbiology. Vol. 8(12), pp. 1360-
1367, 19 March, 2014

Robert, P. Nugent, Marijane. A. Krohn and Sharon L Hillier Reliability of Diagnosing Bacterial Vaginosis Is Improved by a Standardized Method of Gram Stain Interpretation Journal of clinical microbiology, Feb 1991, pg. 207-301

Rotimi, V.O., Z. Yakubu, O. O. Abudu and T. O. Banjo.Direct Gram's stain of vaginal discharge as a means of diagnosing bacterial vaginosis. J. Med. Microbiol. Vol. 35 (1991), 103-106 c. 1991. The Pathological Society of Great Britain and Ireland.

Samuel Ratnam and Barbara. L. Fitzgerald. Semiquantitative Culture of Gardnerella vaginalis in Laboratory Determination of Nonspecific Vaginitis. Journal of Clinical Microbiology Aug. 1983, P. 344-347 Vol. 18, No. 2

\section{How to cite this article:}

Sumangala, B., Akshatha B. Sangannavar, N.S. Sahana Shetty and Kavya Shree M. Arun. 2018. Study of Leucorrhea Cases by Gram Stain and Aerobic Bacterial Culture. Int.J.Curr.Microbiol.App.Sci. 7(02): 1484-1503. doi: https://doi.org/10.20546/ijcmas.2018.702.180 